\title{
Awareness and Impact of Hydroxychloroquine / Chloroquine prophylaxis among the Healthcare Workers during the COVID-19 Pandemic: An observational study.
}

\section{Silky Dhamija}

Symbiosis international university

Yayati Joshi ( $\nabla$ dryayatijoshi@gmail.com )

Symbiosis international university

\section{Amar Nandhakumar}

Kovai meidcal centre and hospital

\section{Research Article}

Keywords: COVID19, Hydroxychloroquine prophylaxis, Healthcare workers, Chloroquine.

Posted Date: June 26th, 2020

DOI: https://doi.org/10.21203/rs.3.rs-37545/v1

License: (c) (i) This work is licensed under a Creative Commons Attribution 4.0 International License. Read Full License 


\section{Abstract}

Background Various modalities are under study for prevention and treatment of novel coronavirus. One such modality is use of Hydroxychloroquine/Choloroquine. The objective of survey was to understand the awareness and impact of HCQ/CQ prophylaxis among the health care workers (HCWs) including surgeons and anaesthetists.

Methods A web-based, cross-sectional survey was conducted for HCWs globally. Participation was voluntary and confidentiality was maintained by making participants' information anonymous. The questionnaire consisted of 28 items. Data were tabulated in excel, and descriptive statistics were performed.

Results Survey was taken by $344 \mathrm{HCW}$ from all over the world. 98\% participants heard about the use of HCQ/CQ prophylaxis against COVID 19 infection. $301 \mathrm{HCWs}$ knew about the side effects of HCQ/CQ. 54 1\% participants agree there is not adequate research done. 122 participants took HCQ/CQ prophylaxis. Out of $295 \%$ participants who received the medicine from hospital under hospital protocol, $667 \%$ were given medication without baseline investigations and $305 \% \mathrm{HCW}$ were not even briefed about the drug and its side effects by the hospitals. $362 \%$ participants developed side effects. 8 7\% HCWs were tested for COVID19 out of 344 participants.

Conclusion The drug taken by HCWs was without adequate evidence, prior investigations, supervision and followup. Most of the participants self prescribed the drug. No separate guidelines were stated for people who had comorbid conditions. Hospitals neither conducted baseline investigations and nor briefed HCWs about HCQ/CQ. These are some serious concerns we are looking into as who will be answerable in case of adverse events.

\section{Introduction}

Coronavirus is a novel virus which has created the pandemic crisis. Most of the studies that are being done to understand its pathophysiology, course of the disease and its management are either small sample studies or single arm studies. It has involved everyone in healthcare system from multipurpose workers to surgeons, fighting on the frontline. Every department in hospital is serving to these patients in their own way. Surgeons and Anaesthetists are actively involved not only in operating these patients under emergency but also are involved in managing these patients in wards and ICU.

SARS-CoV-2 seems to have originated from bats and first report of cases were from Wuhan, Hubei Province in China, suggesting an animal-to-human spread from a live animal market[1]. The World Health Organization (WHO) declared coronavirus disease as a pandemic on March 11, 2020[2].

In the current global scenario where every healthcare system of the world is busy in finding the cure through drugs and vaccines, the only definitive management we know is prevention. Prevention by social distancing, hand hygiene and staying at home. Amidst this global chaos, there are a group of people who are out of their houses and serving the needy and the diseased, by risking their lives. This condition in turn has created a panic among these healthcare workers (HCWs) of being getting infected with COVID19. Fear is a normal human reaction that protects us by signalling danger and preparing us to deal with it. People tend to avoid the situations they fear or they overcome it. When a tendency to fear is present in excess, its consequences are not always helpful.

The National Task Force for COVID 19 constituted by Indian council of medical research (ICMR) under the ministry of health and family welfare issued the guidelines[3] dated $21^{\text {st }}$ March 2020 on prophylactic use of Hydroxychloroquine/Chloroquine(HCQ/CQ) against SARS-CoV-2 for high risk population, including asymptomatic 
healthcare workers involved in direct care of suspected or confirmed cases of COVID 19. The document states "its use in prophylaxis is derived from available evidence of benefit as treatment and supported by preclinical data"[4]. Although some in-vitro evidence supports the antiviral activity of hydroxychloroquine and its precursor chloroquine, there is no peer-reviewed publication that evaluates either drug for exposure prophylaxis of SARS-CoV-2 infection[4]. A letter of correspondence published with The Lancet stated that "We are deeply concerned that in this environment of global panic, an endorsement by the highest scientific body of India (and also by the President of the USA) will create an overly optimistic perception of the effectiveness of hydroxychloroquine among the public. Markets in the USA are already reporting a short supply of both hydroxychloroquine and chloroquine. The situation in India is no different, probably indicating widespread self-medication"[4]. A tweet by President Trump on $21^{\text {st }}$ March 2020 claiming that "the combination of HCQ and azithromycin has a real chance to be one of the biggest game changers in the history of medicine" accelerated a worldwide run on the drugs, with pharmacies reporting shortages within 24 hours[5].

Hydroxychloroquine is a well established drug that has indications for various diseases like malaria, systemic lupus erythematosus and rheumatoid arthritis. Looking this from a different perspective, the well established are the indications so are the side effects and the precautionary warnings. Ocular manifestations, cardiac side-effects, hypoglycaemia are a few to name[6].

So to understand the awareness and knowledge of HCQ/CQ among the health care workers in this panic situation, we decided to do a voluntary survey with a set of 30 questions which will help the HCWs to better understand the drug and its impact.

Out of the various fields, we chose to study the awareness and impact of HCQ/CQ on health care workers. Seeing the excessive use of HCQ/CQ by the health care workers in the vicinity and the little knowledge they carried about the drug, intrigued us to find out the various aspect of it and hence we started this survey.

\section{Methodology}

\section{Basis, Generation and Propagation of Survey}

This survey was conducted at a tertiary-care hospital from $16^{\text {th }}-30^{\text {th }}$ April 2020 . A web-based, cross-sectional study was conducted using a survey instrument to obtain responses from HCWs globally. A 28 item questionnaire survey was generated on online survey tool, the surveyplanet and branching of questions was done to get the targeted results. The question branching controls which questions the participants see based on their responses to previous questions. The link was mailed to the potential responders who included doctors, nurses, technicians and other healthcare staff globally through social networking sites and applications. The total time to complete the survey was estimated to be 3-5 minutes. A total of 344 responders completed the survey. The 28 -item questionnaire (Appendix 1) was divided into 3 sub-headings: Sociodemographics (8 items), Awareness (6 items) and Impact of HCQ/CQ prophylaxis on HCWs (14 items).

\section{Statistical Analysis}

Convenient sampling method was used for data collection, and the distribution of responses was presented as frequency and percentages. Data were tabulated in excel, and descriptive statistics were performed using SPSS 17. 
The Institutional Ethics Committee (IEC) reviewed and approved the study. Confidentiality of personal information was maintained throughout the study by making participants' information anonymous .Eligible HCWs'

participation in this survey was voluntary and was not compensated. Electronic informed consent was shown on the initial page of the survey, such that by taking the survey they automatically consented for the survey. The study was performed following the Declaration of Helsinki as revised in 2013. The study was conducted following the Checklist for Reporting Results of Internet E-Surveys (CHERRIES) guidelines[7]. (Appendix 2)

\section{Results}

Sociodemographics (Table 1)

This survey was taken by $344 \mathrm{HCWs}$ from all over the world with majority of them being from India. Out of these $344 \mathrm{HCWs}, 40$ 7\% were females, $59 \%$ were male. Maximum HCWs belonged to age group of 18 to 40 years (64\%).

Majority of HCWs were from large tertiary centre (62 2\%) and were anaesthesiologist/intensivist (32 3\%)(Figure 1). Out of $344 \mathrm{HCWs}, 222$ participants worked in facilities which provided care to suspected / known COVID19 patients and 130 participants were directly involved in their care.

Table 1. Sociodemographic data of the Healthcare workers. 


\section{DEMOGRAPHICS}

\begin{tabular}{|c|c|c|c|}
\hline & SUB - GROUPS & FREQUENCY & PERCENTAGE \\
\hline \multirow[t]{4}{*}{ Age (years) } & $18-40$ & 220 & $64 \cdot 0$ \\
\hline & $40-60$ & 105 & $30 \cdot 5$ \\
\hline & $>60$ & 19 & $5 \cdot 5$ \\
\hline & Total & 344 & $100 \cdot 0$ \\
\hline \multirow[t]{4}{*}{ Gender } & Female & 140 & $40 \cdot 7$ \\
\hline & Male & 203 & $59 \cdot 0$ \\
\hline & Undisclosed & 1 & $0 \cdot 3$ \\
\hline & Total & 344 & $100 \cdot 0$ \\
\hline \multirow{21}{*}{ Country of work when filling in the survey? } & Afghanistan & 4 & $1 \cdot 2$ \\
\hline & Antigua and Barbuda & 1 & $0 \cdot 3$ \\
\hline & Bahrain & 1 & $0 \cdot 3$ \\
\hline & Bangladesh & 1 & $0 \cdot 3$ \\
\hline & Canada & 1 & $0 \cdot 3$ \\
\hline & Fiji & 1 & $0 \cdot 3$ \\
\hline & France & 1 & $0 \cdot 3$ \\
\hline & Germany & 2 & $0 \cdot 6$ \\
\hline & India & 297 & $86 \cdot 3$ \\
\hline & Italy & 8 & $2 \cdot 3$ \\
\hline & Malaysia & 1 & $0 \cdot 3$ \\
\hline & Malta & 1 & $0 \cdot 3$ \\
\hline & Mexico & 1 & $0 \cdot 3$ \\
\hline & Saudi Arabia & 2 & $0 \cdot 6$ \\
\hline & Singapore & 3 & $0 \cdot 9$ \\
\hline & Spain & 4 & $1 \cdot 2$ \\
\hline & Ukraine & 1 & $0 \cdot 3$ \\
\hline & $\begin{array}{l}\text { United Arab Emirates } \\
\text { (UAE) }\end{array}$ & 4 & $1 \cdot 2$ \\
\hline & United Kingdom (UK) & 5 & $1 \cdot 5$ \\
\hline & $\begin{array}{l}\text { United States of America } \\
\text { (USA) }\end{array}$ & 5 & $1 \cdot 5$ \\
\hline & Total & 344 & $100 \cdot 0$ \\
\hline \multirow[t]{8}{*}{ Speciality or usual place of work } & Emergency room & 13 & $3 \cdot 8$ \\
\hline & Hospital wards & 44 & $12 \cdot 7$ \\
\hline & Intensive Care Unit & 50 & $14 \cdot 5$ \\
\hline & Operation Theatre & 134 & $39 \cdot 0$ \\
\hline & Outpatient Department & 49 & $14 \cdot 2$ \\
\hline & $\begin{array}{l}\text { Research/Clinical } \\
\text { Laboratory }\end{array}$ & 9 & $2 \cdot 7$ \\
\hline & Others & 45 & $13 \cdot 1$ \\
\hline & TOTAL & 344 & 100 \\
\hline \multirow[t]{5}{*}{ Designation } & $\begin{array}{l}\text { Anaesthesiologist/ } \\
\text { Intensivist }\end{array}$ & 111 & $32 \cdot 3$ \\
\hline & $\begin{array}{l}\text { Cleaning and maintenance } \\
\text { - operational services }\end{array}$ & 1 & $0 \cdot 3$ \\
\hline & Dentist & 2 & $0 \cdot 6$ \\
\hline & $\begin{array}{l}\text { Doctor in training } \\
\text { (Intern/Resident) }\end{array}$ & 19 & $5 \cdot 5$ \\
\hline & $\begin{array}{l}\text { General medical } \\
\text { practitioners }\end{array}$ & 40 & $11 \cdot 6$ \\
\hline
\end{tabular}




\begin{tabular}{|c|c|c|c|}
\hline & HCW not classified here & 18 & $5 \cdot 2$ \\
\hline & $\begin{array}{l}\text { Home based personal care } \\
\text { worker }\end{array}$ & 1 & $0 \cdot 3$ \\
\hline & Midwifery professional & 2 & $0 \bullet 6$ \\
\hline & Nursing professional & 32 & $9 \cdot 3$ \\
\hline & Paramedical practitioner & 9 & $2 \cdot 6$ \\
\hline & Physiotherapist & 2 & $0 \cdot 6$ \\
\hline & Respiratory therapist & 4 & $1 \cdot 2$ \\
\hline & $\begin{array}{l}\text { Specialist medical } \\
\text { practitioners }\end{array}$ & 103 & $29 \cdot 9$ \\
\hline & Total & 344 & $100 \cdot 0$ \\
\hline \multirow[t]{6}{*}{ Type of hospital } & Community, urban hospital & 64 & $18 \cdot 6$ \\
\hline & $\begin{array}{l}\text { Large tertiary teaching } \\
\text { hospital }\end{array}$ & 214 & $62 \cdot 2$ \\
\hline & Other & 31 & $9 \cdot 0$ \\
\hline & Polyclinic & 16 & $4 \cdot 7$ \\
\hline & Remote/regional hospital & 19 & $5 \cdot 5$ \\
\hline & Total & 344 & $100 \cdot 0$ \\
\hline \multirow{3}{*}{$\begin{array}{l}\text { Do you work at a facility that has cared/ is caring for } \\
\text { patients with suspected or known COVID-19 infection? }\end{array}$} & No & 122 & $35 \cdot 5$ \\
\hline & Yes & 222 & $64 \cdot 5$ \\
\hline & Total & 344 & $100 \cdot 0$ \\
\hline \multirow{3}{*}{$\begin{array}{l}\text { Have you provided } \\
\text { /providing direct care to the patients with suspected or } \\
\text { known COVID-19 infection? }\end{array}$} & No & 214 & $62 \cdot 2$ \\
\hline & Yes & 130 & $37 \cdot 8$ \\
\hline & Total & 344 & $100 \cdot 0$ \\
\hline
\end{tabular}

\section{Awareness (Table 2)}

HCWs were questioned about their knowledge of HCQ/CQ prophylaxis. 98\% participants heard about the use of HCQ/CQ prophylaxis against COVID 19 infection and most common medium was national/state guidelines(23 4\%) (Figure 2).18 4\% participants admitted, they have heard it as word of mouth from colleagues. Overall 49 7\% participants admitted that they were not briefed about the use of HCQ prophylaxis by the hospital (Figure 1).

Total 301 (87 5\%) HCWs knew about the side effects of HCQ/CQ.HCWs were asked about the reason for not taking $\mathrm{HCQ} / \mathrm{CQ}$ prophylaxis and $375 \%$ participants answered due to the inadequate literature available supporting its use against COVID19. $155 \%$ participants were scared to use it because of its known side effects. 54 1\% participants think there is not adequate research done on use of HCQ/CQ prophylaxis against COVID19.

Table2. Awareness of Hydroxychloroquine/Chloroquine prophylaxis among Healthcare workers tabulated under 6 headings 
AWARENESS

\begin{tabular}{|c|c|c|c|}
\hline & SUB - GROUPS & FREQUENCY & PERCENTAGE \\
\hline \multirow{3}{*}{$\begin{array}{l}\text { Have you heard of HCQ / Chloroquine prophylaxis } \\
\text { against COVID } 19 \text { infection? }\end{array}$} & No & 7 & $2 \cdot 0$ \\
\hline & Yes & 337 & $98 \cdot 0$ \\
\hline & Total & 344 & $100 \cdot 0$ \\
\hline \multirow{7}{*}{$\begin{array}{l}\text { If yes, how do you know about HCQ/ Chloroquine } \\
\text { prophylaxis? }\end{array}$} & Television & 71 & $20 \cdot 6$ \\
\hline & Pharmacy & 16 & $4 \cdot 7$ \\
\hline & Internet & 145 & $42 \cdot 2$ \\
\hline & Hospital protocol & 105 & $30 \cdot 5$ \\
\hline & National/state guidelines & 171 & $49 \cdot 7$ \\
\hline & Colleagues & 135 & $39 \cdot 2$ \\
\hline & $\begin{array}{l}\text { International health } \\
\text { organisations }\end{array}$ & 89 & $25 \bullet 9$ \\
\hline \multirow{4}{*}{$\begin{array}{l}\text { Do you know about the side effects of HCQ/ } \\
\text { Chloroquine? }\end{array}$} & No & 11 & $3 \cdot 2$ \\
\hline & Yes & 301 & $87 \cdot 5$ \\
\hline & Unsure & 32 & $9 \cdot 3$ \\
\hline & Total & 344 & $100 \cdot 0$ \\
\hline \multirow{4}{*}{$\begin{array}{l}\text { Do you think there is adequate research on use of } \\
\text { HCQ / Chloroquine as prophylaxis against COVID-19 } \\
\text { infection? }\end{array}$} & No & 186 & $54 \cdot 1$ \\
\hline & Unsure & 107 & $31 \cdot 1$ \\
\hline & Yes & 51 & $14 \cdot 8$ \\
\hline & Total & 344 & $100 \cdot 0$ \\
\hline \multirow{4}{*}{$\begin{array}{l}\text { Have you been briefed about use of HCQ/ } \\
\text { Chloroquine for prophylaxis by hospital authorities? }\end{array}$} & No & 171 & $49 \cdot 7$ \\
\hline & Yes & 149 & $43 \cdot 3$ \\
\hline & Unsure & 24 & $7 \cdot 0$ \\
\hline & Total & 344 & $100 \cdot 0$ \\
\hline \multirow[t]{3}{*}{ Reason for not taking HCQ/CQ prophylaxis } & $\begin{array}{l}\text { Literature supports its } \\
\text { ineffectiveness against COVID19 }\end{array}$ & 23 & $10 \cdot 4$ \\
\hline & $\begin{array}{l}\text { Inadequate literature available } \\
\text { supporting its use against } \\
\text { COVID19 }\end{array}$ & 130 & $58 \cdot 6$ \\
\hline & Non Availability of drug & 14 & $6 \cdot 3$ \\
\hline
\end{tabular}

Page $7 / 16$ 


\begin{tabular}{|l|l|l|} 
Due to its known side effects & 55 & $24 \cdot 7$ \\
\hline $\begin{array}{l}\text { Already taking it for some other } \\
\text { co morbid condition }\end{array}$ & 0 & 0 \\
\hline Total & 222 & $100 \bullet 0$ \\
\hline
\end{tabular}

Impact (Table 3)

Out of 122 participants who took HCQ prophylaxis, 56 participants self prescribed the drug and remaining were either prescribed by medical practitioners or followed National/State/hospital protocols. Among $295 \%$ participants who received the medicine from hospital under hospital protocol, $667 \%$ were given medication without baseline investigations like ECG, G6PD levels and 30 5\% HCWs were not even briefed about the drug and its side effects by the hospitals.

$493 \%$ of 122 participants, who took HCQ/CQ prophylaxis, had common co-morbid diseases like hypertension and diabetes mellitus and others. Among 34 (36 2\%) participants who developed side effects while on HCQ/CQ only 61 $8 \%$ of them were sure that it was because of $\mathrm{HCQ} / \mathrm{CQ}$, remaining were unaware. Most common side effect observed was headache followed by nausea and vomiting, abdominal pain, anorexia, impaired vision, hypoglycaemia diarrhoea.4 participants developed chest pain and discomfort. Only $147 \%$ participants who developed side effects consulted a doctor.

$656 \%$ HCWs took $400 \mathrm{mg} \mathrm{HCQ}$ twice daily on day 1 followed by $400 \mathrm{mg}$ once a week for 7 weeks. Among the total 122 participants who took HCQ/CQ prophylaxis, 83(63 4\%) of them did not do any investigation like ECG or G6PD levels prior to starting HCQ/CQ even though

78 participants were aware of the side effects.

Statistically quoting, 60 participants have given HCQ/CQ as prophylaxis to their relatives who are not directly exposed to COVID19 patients.

Only 8 7\% HCWs were tested for COVID19 out of 344 participants, 2 were confirmed positive and 4 participants were waiting for results.

Table 3. Awareness of Hydroxychloroquine/Chloroquine prophylaxis among Healthcare workers tabulated under 13 headings. 
IMPACT

\begin{tabular}{|c|c|c|c|}
\hline & SUB - GROUPS & FREQUENCY & PERCENTAGE \\
\hline \multirow{3}{*}{$\begin{array}{l}\text { Have you taken HCQ/ Chloroquine } \\
\text { prophylaxis? }\end{array}$} & Yes & 122 & $35 \cdot 5$ \\
\hline & No & 222 & $64 \cdot 5$ \\
\hline & Total & 344 & $100 \cdot 0$ \\
\hline \multirow{5}{*}{$\begin{array}{l}\text { Who prescribed you HCQ/Chloroquine } \\
\text { prophylaxis? }\end{array}$} & Hospital Protocol & 36 & $29 \cdot 5$ \\
\hline & Medical practitioner & 13 & $10 \cdot 7$ \\
\hline & National/ State guidelines & 17 & $13 \cdot 9$ \\
\hline & Self & 56 & $45 \cdot 9$ \\
\hline & Total & 122 & $100 \cdot 0$ \\
\hline \multirow[t]{7}{*}{$\begin{array}{l}\text { Which HCQ / Chloroquine prophylaxis } \\
\text { regimen are you following? }\end{array}$} & $\begin{array}{l}\text { 200mg HCQ once a day for } 2 \text { days, } \\
\text { followed by } 200 \mathrm{mg} \text { once weekly for next } \\
14 \text { weeks }\end{array}$ & 1 & $0 \cdot 8$ \\
\hline & $\begin{array}{l}200 \mathrm{mg} \mathrm{HCQ} \text { once a day for } 2 \text { days, } \\
\text { followed by } 200 \mathrm{mg} \text { once weekly for next } \\
7 \text { weeks }\end{array}$ & 5 & $4 \cdot 1$ \\
\hline & $\begin{array}{l}400 \mathrm{mg} \text { HCQ twice a day on day } 1, \\
\text { followed by } 400 \mathrm{mg} \text { once weekly for next } \\
3 \text { weeks }\end{array}$ & 28 & 23 \\
\hline & $\begin{array}{l}400 \mathrm{mg} \text { HCQ twice a day on day } 1 \\
\text { followed by } 400 \mathrm{mg} \text { once weekly for next } \\
7 \text { weeks }\end{array}$ & 80 & $65 \cdot 6$ \\
\hline & $\begin{array}{l}\text { Chloroquine } 500 \mathrm{mg} \text { twice daily for } 10 \\
\text { days }\end{array}$ & 2 & $1 \cdot 6$ \\
\hline & Others & 6 & $4 \cdot 9$ \\
\hline & Total & 122 & $100 \cdot 0$ \\
\hline \multirow{4}{*}{$\begin{array}{l}\text { Did you do baseline investigations before } \\
\text { starting on HCQ/ Chloroquine?(Multiple } \\
\text { answers ) }\end{array}$} & $\overline{E C G}$ & 38 & 29 \\
\hline & G6PD levels & 10 & $7 \cdot 6$ \\
\hline & None & 83 & $63 \cdot 4$ \\
\hline & Total & 122 & 100 \\
\hline \multirow{3}{*}{$\begin{array}{l}\text { Do you have any co morbidities? (Multiple } \\
\text { answers) }\end{array}$} & Hypertension & 26 & $18 \cdot 3$ \\
\hline & Diabetes mellitus & 15 & $10 \cdot 6$ \\
\hline & Ischemic heart disease & 1 & $0 \cdot 8$ \\
\hline
\end{tabular}

Page 9/16 


\begin{tabular}{|c|c|c|c|}
\hline & Obesity & 8 & $5 \cdot 6$ \\
\hline & Rheumatic arthritis & 2 & $1 \cdot 6$ \\
\hline & G6PD deficiency & 0 & 0 \\
\hline & Past history of malaria & 9 & $6 \cdot 3$ \\
\hline & Others & 9 & $6 \cdot 3$ \\
\hline & None & 72 & $50 \cdot 7$ \\
\hline & Total & 122 & $100 \bullet 0$ \\
\hline \multirow{9}{*}{$\begin{array}{l}\text { Did you develop any of these symptoms } \\
\text { while on HCQ / Chloroquine?(multiple } \\
\text { answers) }\end{array}$} & Headache & 14 & $10 \cdot 1$ \\
\hline & Chest pain/Discomfort, & 4 & $3 \cdot 2$ \\
\hline & Anorexia, & 3 & $2 \cdot 4$ \\
\hline & Nausea/vomiting & 11 & 8 \\
\hline & Abdominal pain & 9 & $6 \cdot 5$ \\
\hline & Impaired vision (Ocular complications) & 1 & $0 \bullet 8$ \\
\hline & Others & 8 & $5 \cdot 8$ \\
\hline & None & 88 & $63 \cdot 8$ \\
\hline & Total & 122 & $100 \cdot 0$ \\
\hline \multirow{4}{*}{$\begin{array}{l}\text { Do you think these symptoms were /are due } \\
\text { to HCQ/Chloroquine? }\end{array}$} & No & 3 & $8 \cdot 8$ \\
\hline & Unsure & 10 & $29 \cdot 4$ \\
\hline & Yes & 21 & $61 \cdot 8$ \\
\hline & Total & 34 & $100 \cdot 0$ \\
\hline \multirow{3}{*}{$\begin{array}{l}\text { Did you consult a doctor after developing } \\
\text { above mentioned symptoms? }\end{array}$} & No & 29 & $85 \cdot 3$ \\
\hline & Yes & 5 & $14 \cdot 7$ \\
\hline & Total & 34 & $100 \cdot 0$ \\
\hline \multirow{3}{*}{$\begin{array}{l}\text { Are you presently on } \mathrm{HCQ} / \text { Chloroquine for } \\
\text { treatment of any other illness? }\end{array}$} & No & 326 & $94 \bullet 8$ \\
\hline & Yes & 18 & $5 \cdot 2$ \\
\hline & Total & 344 & $100 \cdot 0$ \\
\hline \multirow{3}{*}{$\begin{array}{l}\text { Is anyone in your family taking HCQ / } \\
\text { Chloroquine? }\end{array}$} & No & 284 & $82 \cdot 6$ \\
\hline & Yes & 60 & $17 \cdot 4$ \\
\hline & Total & 344 & $100 \cdot 0$ \\
\hline
\end{tabular}




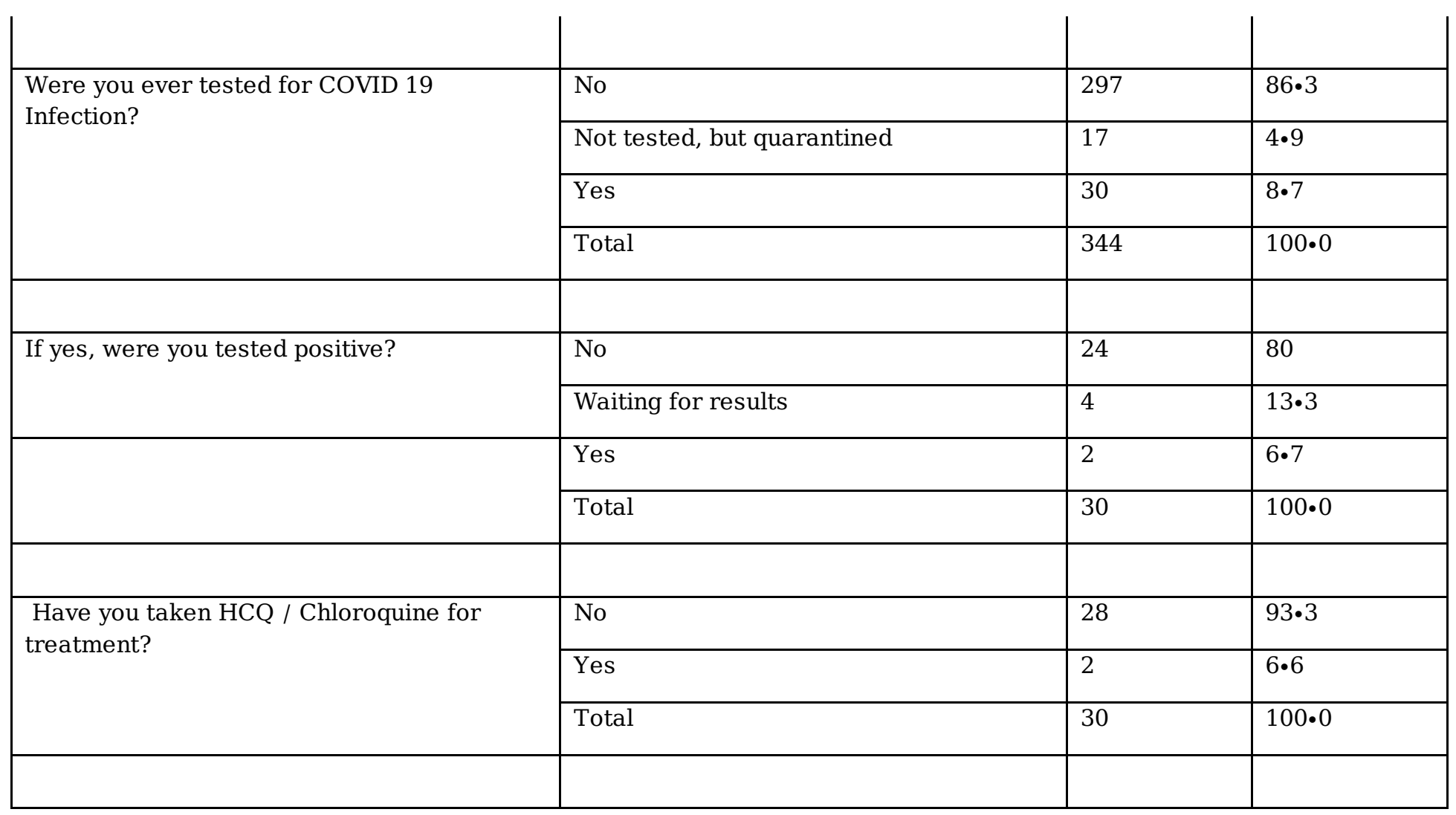

\section{Discussion}

The world is seeing a pandemic at such a massive scale after 1918 Spanish Flu. While the scientist and researchers all over the world are engrossed in inventing a vaccine or a treatment for COVID19, it is our moral responsibility to keep things in order to stop its expansion. In doing so, we may feel perturbed and many things may go wrong although they are not intended to. This so called collateral damage needs to be surveyed and controlled. For times like these WHO designed MEURI in 2018 after Ebolavirus outbreak[8].

In our study majority of participants worked in large tertiary hospitals. Almost all of them had heard about HCQ/CQ use as prophylaxis against covid19 infection but their source of information was vague and unreliable. Even though the participants belonged to specialized group, their knowledge of this trial drug was insufficient. Most of them were aware that the research data on HCQ/CQ use as prophylaxis is very limited but they still took the prophylaxis. One of the reasons could be the bold statements made in news media by the concern authorities and the national and state guidelines recommending the same. The fear of acquiring the infection by this high risk group led to the widespread use of $\mathrm{HCQ} / \mathrm{CQ}$, even by their family members overlooking the harm the drug may cause.

We observed that $362 \%$ participants who took the prophylaxis developed the side effects. Only few of them got tested for taking the medication, which could have lead to deleterious effects. Most of the participants self prescribed in order to be safe during the pandemic crisis.

After studying these results, we were paralysed with fear that a drug with serious side effects[9] is being taken by HCWs without adequate evidence, prior investigations, supervision and follow-up. In some countries, before conducting clinical trial on humans, $\mathrm{HCQ} / \mathrm{CQ}$ was already recommended by the national guidelines[3]. No separate guidelines were stated for people who had co-morbid conditions. Even some hospitals who followed use of HCQ/CQ prophylaxis protocol to combat COVID 19 did not conduct baseline investigations before giving the medication. 
Majority of HCWs were not briefed by hospital authorities about HCQ/CQ which is of utmost priority especially during this time of pandemic when there are only drug trials in the name of treatment.

Almost all HCWs who took HCQ/CQ prophylaxis were aware of the side effects but still very few of them did baseline investigation like ECG, to rule out prolonged QT, which is the common adverse effect of the drug.

The social trepidation around COVID19 is so dreadful that the HCWs who are expected to be sane and rational in these difficult times have lost the credence in medicine. This panic has put the HCWs at the risk of self immolation. There are quite good number of cases reported where the false assurance of HCQ prophylaxis has led to mortality in general public as well as HCWs. This falsification has increased the demand of HCQ to such an extent that American college of Physicians has published their concerns and opinions to overcome the scarcity of HCQ for those patients who are already on treatment for illnesses other than COVID19[5].

Not to mention that in vitro studies[10-12] supported by a small study of France[13] have led to this perplexity. Sun Hee Lee, Hyunjin Son, and Kyong Ran Peck[14] conducted a study on post exposure prophylaxis (PEP) using hydroxychloroquine (HCQ) on 211 persons, whose baseline polymerase chain reaction (PCR) tests for COVID-19 were negative. PEP was completed in 184 (97 4\%) patients and 21 (95 5\%) care workers without serious adverse events. At the end of 14 days of quarantine, follow-up PCR tests were all negative. Based on their experience, they implemented PEP with HCQ safely under proper monitoring.

A systematic review of 45 articles on prophylaxis of HCQ/CQ in COVID-19 pandemic published by Sanket Shah, Saibal Das, Avinash Jain, Durga Prasanna Misra, and Vir Singh Negi[15] concluded that although pre-clinical results are promising till date, there is dearth of evidence to support the efficacy of CQ or HCQ in preventing COVID-19. Considering potential safety issues and the likelihood of imparting a false sense of security, prophylaxis with CQ or HCQ against COVID-19 needs to be thoroughly evaluated in observational studies or high quality randomized controlled studies.

The above mentioned figures show lacunae in the guidelines and recommendations. Some of the sincere question arises are- "Why was informed consent advisory not followed as per MEURI? Why not all HCWs were were investigated before starting of the HCQ prophylaxis? What are the recommendations for the participants who were hypertensive and diabetic or who were already on HCQ treatment for other illnesses? Why there were no strict guidelines for the hospitals to educate about HCQ and monitor its usage? After starting of prophylaxis why the HCWs were were not tested for COVID19, to see if it really works as prophylaxis? "

Finally, after the cacophony created by these events, clinical trials are conducted from United States of America ( NCT04308668), Spain ( NCT04304053), Europe and Asia (NCT04303507) to name a few[15]. But we are still unsure and blind about it, just hoping once again science saves the world.

\section{Conclusion}

It was premature to recommend HCQ/CQ as a panacea for prophylaxis of COVID-19 in absence of robust in vivo and clinical trials. Quarantine, social distancing and personal hygiene seems to be the only proven preventative measures in current scenario. Furthermore, the pandemic hysteria that caused unrestricted off-label use HCQ/CQ by common people without adhering to the guidelines has led to deprivation of these essential drugs to other legitimate patients due to mismatch in demand and supply. Thus, further prudency is warranted in this regard. 
The HCWs should be aware and keep them update about the drug trials, its effect and side effect profile before taking any medication as prophylaxis.

HCWS should educate themselves about the strength of available data regarding trial drugs in treating COVID-19.

The concern authorities should take strict measures to avoid misuse of trial drugs and implement guidelines on its use only under supervision.

The hospitals should share the responsibility by educating their HCWs about this new crisis situation and the treatment modalities available to them.

Necessary investigation should be made mandatory before starting trial drug for prophylaxis or treatment.

\section{Limitation}

We believe time plays a major role in these unusual times. And that has restricted us to keep the survey open for longer duration and for more respondents.

Since this was a cross sectional study, participants were not followed up.

\section{Declarations}

\section{ACKNOWLEDGEMENT}

The support of all the healthcare workers who participated in this survey is highly appreciated. We also want to thank Ms Soham Chandratre for her help and support in data analysis.

\section{CONFLICTS OF INTEREST}

None

\section{SOURCE(S) OF SUPPORT}

This research did not receive any specific grant from funding agencies in public, commercial or not for profit sectors.

Funding - Not Applicable

Conflicts of interest/Competing interests - No conflict of interests.

Ethics approval- The Institutional Ethics Committee (IEC) reviewed and approved the study.

Consent to participate - Electronic informed consent was shown on the initial page of the survey, such that by taking the survey they automatically consented for the survey. The study was performed following the Declaration of Helsinki as revised in 2013.

Consent for publication - Not applicable

Availability of data and material - Partially available

Code availability - Not applicable. 


\section{References}

1. Modi P D, Nair G, Uppe A, et al. (April 02, 2020) COVID-19 Awareness Among Healthcare Students and Professionals in Mumbai Metropolitan Region: A Questionnaire-Based Survey. Cureus 12(4): e7514. DOI $10.7759 /$ cureus.7514

2. WHO Director-General's opening remarks at the media briefing on COVID-19 - 11 March 2020. (2020). Accessed: Mar 19, 2020: https://www.who.int/dg/speeches/detail/who-directorgeneral- s-opening-remarks-at-the-mediabriefing-on-covid-19-11-...

3. National Taskforce for COVID-19. Advisory on the use of hydroxy-chloroquine as prophylaxis for SARS-CoV-2 infection. 2020.

https://www.mohfw.gov.in/pdf/AdvisoryontheuseofHydroxychloroquinasprophylaxisforSARSCoV2infection.pdf (accessed March 23, 2020).

4. Sahaj Rathi, Pranav Ish, Ashwini Kalantri, Shriprakash Kalantri Lancet Infect Dis 2020 Published Online April 17, 2020 https://doi.org/10.1016/S1473-3099(20)30313-3

5. Jinoos Yazdany, MD, MPH, and Alfred H.J. Kim, MD, PhD org on 31 March 2020. doi:10.7326/M20-1334

6. https://www.accessdata.fda.gov/drugsatfda_docs/label/2017/009768s037s045s047lbl.pdf

7. Eysenbach G. Improving the quality of Web surveys: the Checklist for Reporting Results of Internet E-Surveys (CHERRIES). J Med Internet Res 2004 Sep 29;6(3):e34 [FREE Full text] [doi: 10.2196/jmir.6.3.e34] [Medline: 15471760]

8. https://www.who.int/ebola/drc-2018/notes-for-the-record-meuri-ebola.pdf visited on 3/5/2020

9. https://www.poison.org/articles/chloroquine-hydroxychloroquine, visited on 3/5/2020.

10. Yao X, Ye F, Zhang M, Cui C, Huang B, Niu P, et al. In Vitro Antiviral Activity and Projection of Optimized Dosing Design of Hydroxychloroquine for the Treatment of Severe Acute Respiratory Syndrome Coronavirus 2 (SARSCoV-2). Clin Infect Dis Off Publ Infect Dis SocAm. 2020;

11. Liu J, Cao R, Xu M, Wang X, Zhang H, Hu H, et al.Hydroxychloroquine, a less toxic derivative of chloroquine, is effective in inhibiting SARS-CoV-2 infection in vitro. Cell Discov. 2020;6:1-4.

12. Wang M, Cao R, Zhang L, Yang X, Liu J, Xu M, et al. Remdesivir and chloroquine effectively inhibit the recently emerged novel coronavirus (2019-nCoV) in vitro. Cell Res. 2020;30:269-71.

13. Gautret_P, Lagier_J-C, Parola_P, Hoang_VT, Meddeb_L, Mailhe_M, et al. Hydroxychloroquine and azithromycin as a treatment of COVID-19: results of an open-label non-randomized clinical trial. International Journal of Antimicrobial Agents 2020 March 20 [Epub ahead of print]. [DOI: 10.1016/j.ijantimicag.2020.105949]

14. Sun Hee Lee, Hyunjin Son, Kyong Ran Peck, Can postexposure prophylaxis for COVID-19 be considered as one of outbreak response strategies in long-term care hospitals?, International Journal of Antimicrobial Agents (2020), doi:https://doi.org/10.1016/j.ijantimicag.2020.105988

15. Sanket Shah, Saibal Das, Avinash Jain, Durga Prasanna Misra, Vir Singh Negi. A systematic review of the prophylactic role of chloroquine and hydroxychloroquine in Coronavirus Disease-19 (COVID-19), international journal of Rheumatic disease, doi:10.1111/1756-185X.13842

\section{Figures}



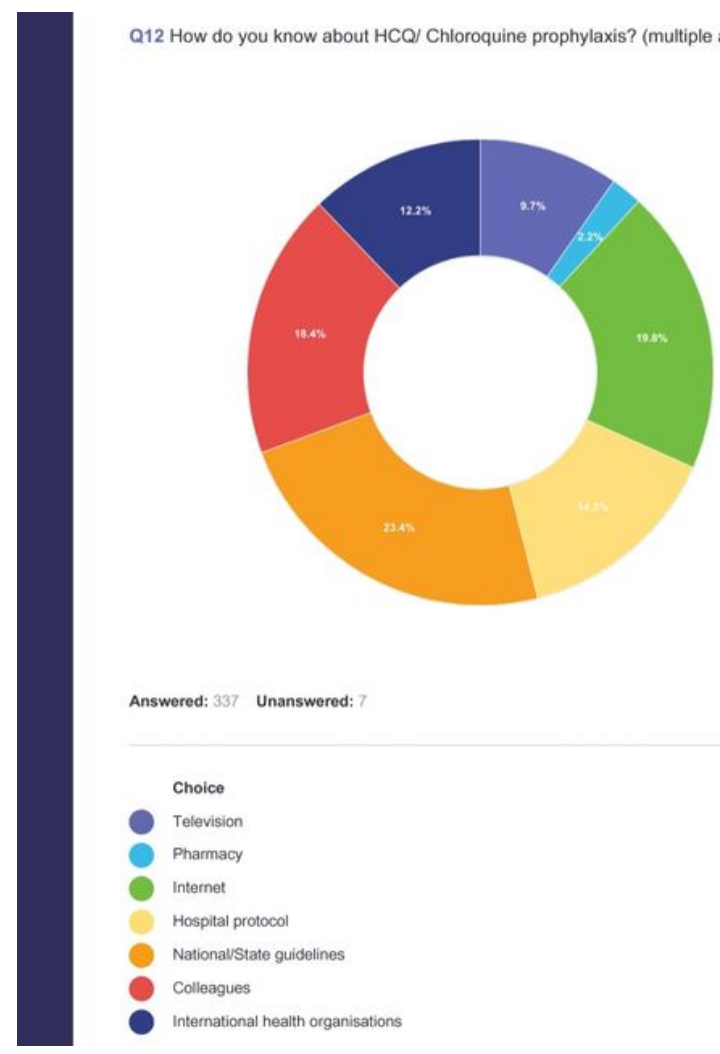

Answered: 337 Unanswered:
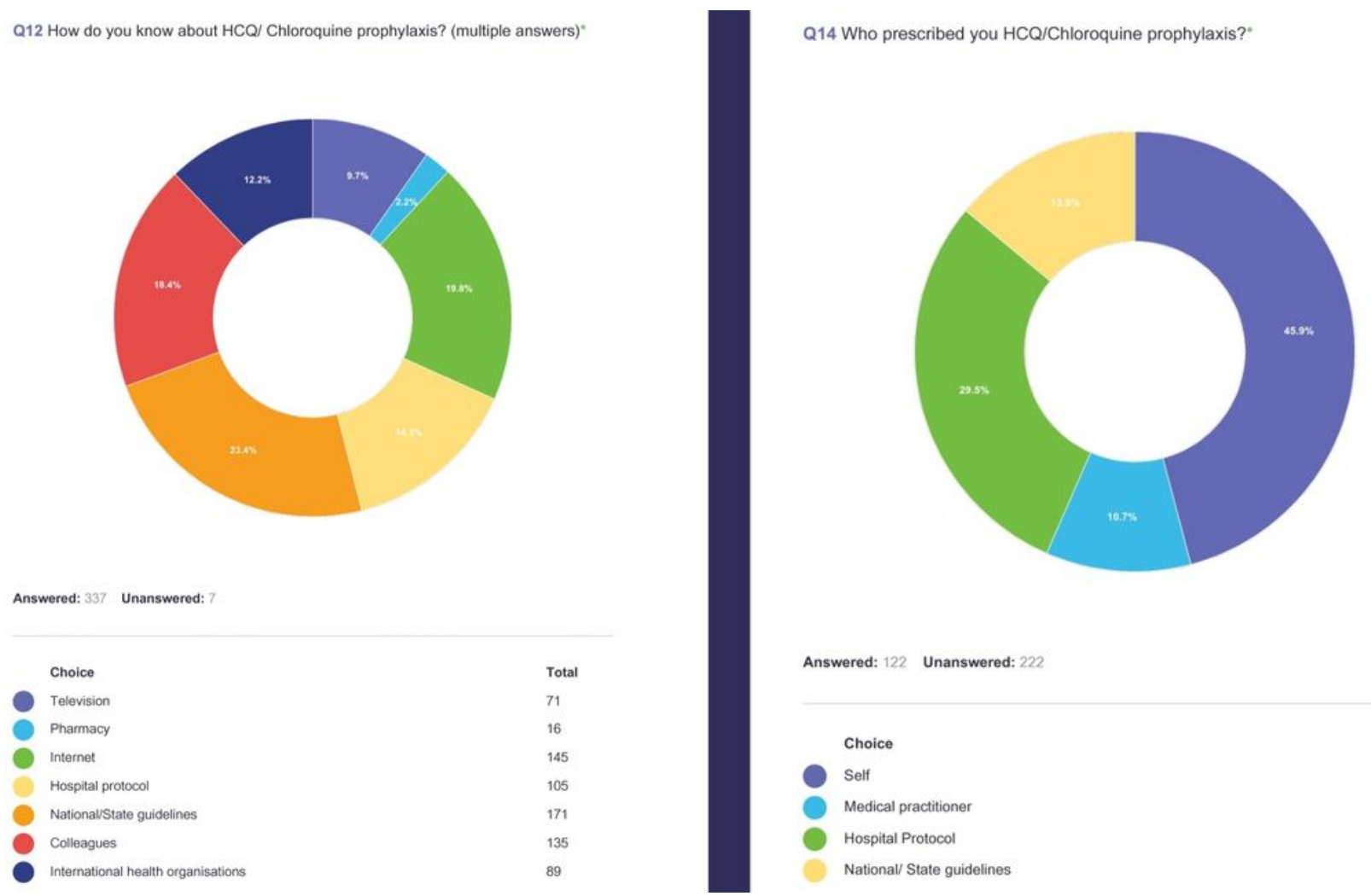

Figure 1

Excerpts of results from Survey

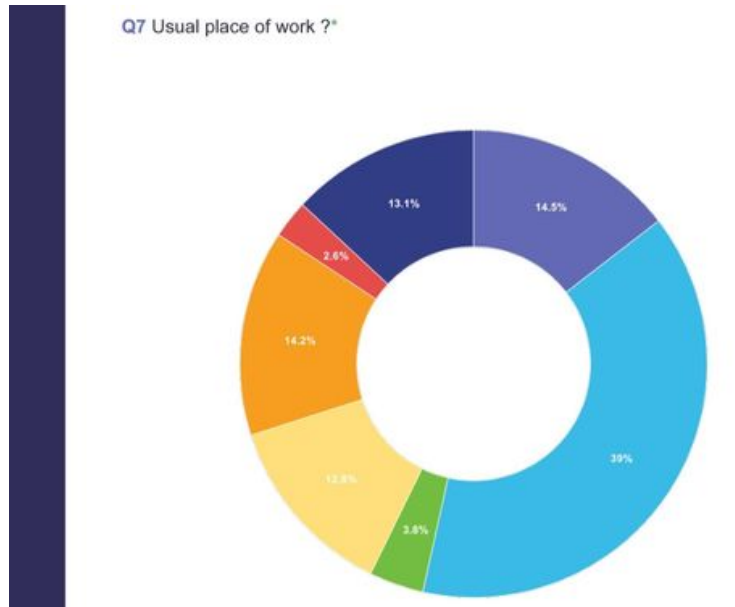

Answered: 344 Unanswered: 0

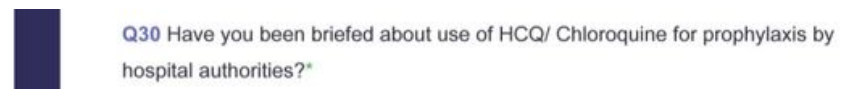

Answered: 122 Unanswered: 222

$\begin{array}{ll}\text { Choice } & \text { Total } \\ \text { Self } & 56 \\ \text { Medical practitioner } & 13 \\ \text { Hospital Protocol } & 36 \\ \text { National/ State guidelines } & 17\end{array}$

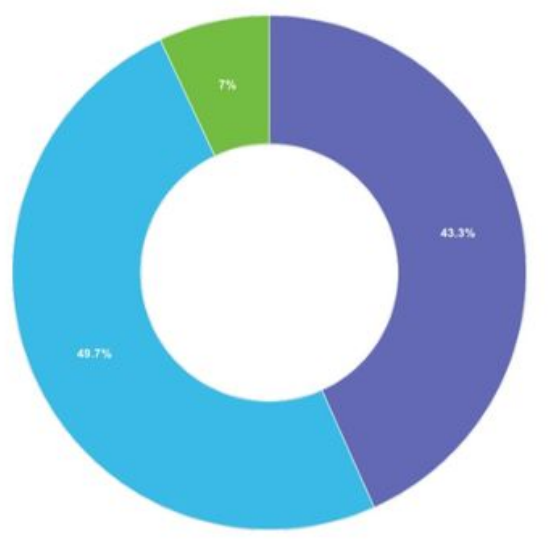

Answered: 344 Unanswered: 0

Choice
Intensive Care Unit
Operation Theatre
Emergency room
Hospital wards
Outpatient Department
Research/Clinical Laboratory
Others (please specify)

Figure 2 


\section{Supplementary Files}

This is a list of supplementary files associated with this preprint. Click to download.

- appendix2.doc

- appendix1.doc 